\title{
Imágenes de una ciudad ansiosa. Sensibilidad visual en la prensa porteña de la década de 1860
}

Pictures of an anxious city. Visual sensitivity in the Buenos Aires press of 1860's

Lucas Andrés Masan

Universidad Nacional del Centro de la Provincia de Buenos Aires, Argentina

andresmasan@gmail.com

\section{ReSUMEN:}

En este trabajo nos adentramos en el universo de la cultura visual de Buenos Aires durante la década de 1860 a través de dos publicaciones periódicas: el Correo del Domingo y El mosquito. Situados en una ciudad abierta y evanescente ante las primeras manifestaciones de modernidad, buscaremos analizar el sitio que ocupan las imágenes en estos productos culturales. Nuestra hipótesis es que durante este período se asiste a una modificación de la sensibilidad visual, caracterizada por la ampliación de los horizontes y un solapamiento de las escalas espaciales, articuladas entre lo micro y lo macroscópico.

Palabras clave: Imagen, Indicios, Buenos Aires, Prensa, Cultura visual.

\section{Abstract:}

In this work we go inside in the visual culture universe of Buenos Aires during the 1860 decade through two periodic publications: the Correo del Domingo and El Mosquito. Located in an open and evanescent city to the firs modernity's manifestations, we search analyze to the place of images in these cultural products. Our hypothesis is through this period it is attended a visual sensitivity modification, characterized by the extension of the horizon's and an overlap of the space scales, articulated between the micro and the macroscopic vision.

KEYwORDS: Image, Indicial, Buenos Aires, Press, Visual culture.

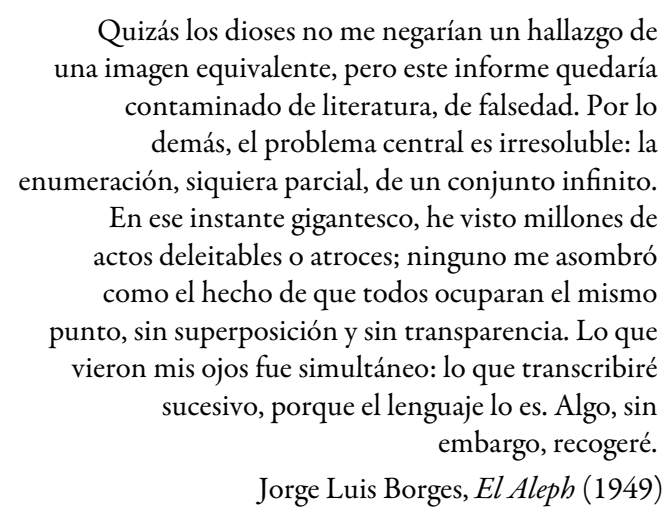

\section{INTRODUCCIÓN}

En este trabajo examinamos la presencia de la imagen en la prensa porteña de la década de 1860 a partir de dos publicaciones: el Correo del domingo y El Mosquito. El argumento que recorre estas páginas es que la ciudad de Buenos Aires ingresa por distintas puertas al mundo moderno durante aquellos años, siendo algunas de esas aberturas palpables en el desarrollo de una nueva sensibilidad, caracterizada por una ampliación de la visualidad y una modificación de los sentidos de espacialidad. Se trata de una sociedad que comienza a ver al mundo y a sí misma de manera diferente: con unos ojos modernos. ${ }^{1}$ Auscultando ciertas huellas iconográficas que nos permiten entrever de qué modo la ciudad se veía y sentía a sí misma, nos interesa penetrar en los modos de concebir el espacio - propio y extraño- y sus posibles motivaciones. Mientras en algunas páginas de la prensa de entonces es posible hallar un protagonismo creciente de lo 
visual -compuesto de imágenes, pero también de tipografías, metáforas o textos literarios-, también se configura un fenómeno de ampliación de horizontes: aludiendo a nuevos escenarios, modificando los existentes y sugiriendo mundos lejanos o prima facie invisibles. Consideramos que estas claves constituyen notas distintivas de una paulatina incorporación del ideario modernizante en la sensibilidad, visible en estas singulares publicaciones.

El término modernidad, en consonancia con su arborescente naturaleza, evoca ideas solapadas que asumen multiplicidad de perfiles. La vastedad de sentidos que adquiere la convierte en una noción problemática, con asociaciones tanto filosóficas, ideológicas, morales o políticas, como cognitivas, tecnológicas y socioeconómicas (Singer, 1996, p. 72). El concepto en singular tanto como su "prudente plural" de "modernidades", encarnan de hecho un "tributo a la turbulencia" por el cual resulta más fácil ejemplificarla que definirla (Gay, 2007, p. 23). En medio de esta "turbulencia" y reparando en su elusividad, entendemos a la modernidad como una modificación de las percepciones, lo cual deviene en un "reacondicionamiento del aparato sensorial del individuo" (Singer, 1996, p. 93), cimentado en "la mutación constante de la ciudad" como elemento característico (Fritzsche, 2008, p. 42). En este territorio de mutaciones situamos nuestro examen.

En rigor las alteraciones que la modernidad trae aparejada en el ámbito de las percepciones son de hecho múltiples, siendo lo visual sólo una de estas facetas. Por consiguiente nos interesa ponderar las modalidades que asumen las imágenes, en tanto condensación de ideas, expectativas y deseos referidos a la modernidad, en un momento transicional como la década de 1860. La importancia de estudiar el ámbito de las percepciones y más precisamente el de la visión - se inscribe con singular adecuación, en tanto "la ubicuidad de la visión" se constituye como "el sentido maestro de la era moderna" (Jay, 2003, p. 222). Además, si uno de los parámetros de la modernidad puede ser considerado el hecho de que la sociedad se piense y proyecte con imágenes (Galassi, 2012), dar cuenta del ambiente visual de entonces posee hondas implicancias.

Considerando junto con Gorelik (2003, p. 9) que "debatir lo moderno en América Latina es debatir la ciudad”, es posible pensar a la Buenos Aires de la década de 1860 como una ciudad efímera y cambiante (Liernur, 1992) que, abierta hacia el mundo (Caimari, 2016, p. 612), concibe su propia existencia en términos modernos promoviendo novedosos estímulos sensoriales. De entre todos ellos, la visión se posiciona como un favorable ámbito en el cual hallar indicios debido a que, como desarrollaremos en estas páginas, Buenos Aires se constituye en un espacio que comienza a perfilarse extendiendo "sus funciones más allá de sus fronteras físicas" (Simmel, 2005, p. 8). Ya en 1864 se ponía de relieve esta nueva textura al percibir que la ciudad "está movible, anhelosa, mira hacia adelante; anda, alienta, se precipita, quiere tener alas" (Correo del domingo, n. ${ }^{\circ}$ $24,12 / 6 / 1864)$. Esto nos permite entrever un régimen de lo sensible que está siendo interpelado, configurado en los emplazamientos de una modernidad emergente, en una ciudad conectada al mundo.

Atendiendo a estas consideraciones, la elección de nuestro material empírico no resulta azarosa sino que obedece al sitio destacado que ocuparon las publicaciones durante estos años, puesto que

Además de protagonista en la vida política de la historia del siglo XIX, la prensa también se convirtió en una de las principales varas con las que midió el grado de libertad de un gobierno y el nivel de "civilización" de una sociedad (Alonso, 2004, p. 8).

A su vez, y si consideramos que la prensa como objeto de estudio de tiempos pretéritos resuena "con una configuración cultural que era mucho más amplia y profunda que la prensa misma” (Caimari, 2018, p. 89), la conexión entre esta y otras producciones puede revelar deseos, sueños y anhelos de una sociedad en plena transformación. Dichas mutaciones se encuentran marcadas por la cadencia de una creciente "ansiedad de mundo", en la cual se perfila cierto apremio de futuro, una necesidad de escrutar y una inquietud por ampliar los horizontes de la visión.

Situando a estas dos publicaciones en los orígenes de la modernidad en Buenos Aires, nos interesa penetrar en las características que asume la imagen en la prensa de mitad del diecinueve, antes de su explosión "moderna" de comienzos del siglo XX (Sidicaro, 1993; Saítta, 1998; Roman, 1999; Bonelli Zapata, 2017). Igualmente, atendemos a las reflexiones que matizan esta periodización mostrando que tales "novedades" 
pueden rastrearse en tiempos decimonónicos (Bonaudo, 2005; Caimari, 2015; Pastormerlo, 2016). Con todo, emprendemos nuestro examen con miras a penetrar en las modalidades por las cuales la imagen encuentra un posicionamiento significativo en estas discursividades, asociadas a la paulatina cristalización de una nueva sensibilidad de carácter visual. La misma promueve, estimula y ofrece ver al mundo en su multiplicidad de aristas, gestionando de distintas maneras la "curiosidad de los porteños" (Telesca y Amigo, 1997).

Bajo estos miramientos estructuramos el trabajo en tres secciones. En la primera damos cuenta de las condiciones culturales que asume el espacio local, indagando en las transformaciones experimentadas por la cultura visual y la prensa durante la década de 1860. En un segundo momento procedemos al abordaje del Correo del Domingo y El mosquito (también referenciados desde ahora como CD y EM respectivamente) a partir de los procedimientos visuales que allí se ponen de manifiesto. En una tercera parte, realizamos una triangulación con otras construcciones icónicas como un modo de examinar las modalidades que asume esta nueva sensibilidad visual con atributos modernos, signada por una novedad escópica y conceptual: el solapamiento de escalas entre lo micro y lo macroscópico. Finalmente ofrecemos algunas de las reflexiones que este recorrido nos sugiere.

El análisis de los documentos será efectuado en clave indiciaria (Freud, 1914; Ginzburg, 1994 y 2013; Burucúa, 2006; Aguirre Rojas, 2017, p. 90), por considerarla una metodología no sólo apropiada sino también históricamente convergente con el período analizado, donde el horizonte visual parece oscilar entre el detalle y la generalidad. Este procedimiento analítico nos permitirá restituir parte de la complejidad de un momento efervescente compuesto por múltiples dimensiones, de entre las cuales destacamos lo visual como modelador de percepciones (Schama, 1996, p. 9). Por tales motivos, las imágenes serán abordadas como un síntoma epocal. Ello implica situar lo visual como un "terreno en disputa" (Jay, 2003) y en esta dirección, preguntarnos en qué coyuntura y bajo qué modalidades es posible hallar claves explicativas de una emergencia de "lo moderno" en la prensa, radicada en una sensibilidad visual en la cual se gestiona un nuevo "modo de ver” (Berger, 1972). Parafraseando a Mitchell (2003, p. 26), el objetivo de este trabajo pretende rastrear tanto la configuración visual de lo espacial, como la construcción espacial de lo visual.

\section{La cultura visual en Buenos Aires durante la década de 1860}

El ocaso del régimen rosista en la batalla de Caseros (1852) trajo una reestructuración del país, en la cual la posición de Buenos Aires resultó singular: se había declarado provincia autónoma y producto de la negativa a firmar la Constitución de 1853 contó desde abril de 1854 con una carta constitucional propia. Ello hizo que, durante casi una década, la nación en formación quedara escindida en dos partes: el Estado de Buenos Aires por un lado y la Confederación Argentina por otro. La unión nacional se materializaría en 1861, con el triunfo de las tropas porteñas en la batalla de Pavón, lo cual provocaría el fin de la Confederación Argentina, la asunción de Bartolomé Mitre en la presidencia en 1862 y el traslado de la capital de Paraná a Buenos Aires (Halperín Donghi, 1982; Oszlak, 1982; Bonaudo, 1999; Bragoni y Míguez, 2010; Sabato, 2012).

En paralelo con estos avatares políticos, ya desde el período de secesión Buenos Aires se perfilaba hacia una reconfiguración de sus contornos como ciudad. Las modificaciones demográficas, urbanísticas y de obra públic xxperimentadas desde mediados del siglo XIX, permiten observar no sólo un aumento del flujo de personas, sino también una transformación de las pautas de sociabilidad, con la explosión del asociacionismo y los espacios de encuentro, reunión e intercambio entre individuos dentro del ámbito urbano (Gayol, 2000; González Bernaldo de Quirós, 2008). Como parte de esta metamorfosis, proliferaron los salones de vistas ópticas, gabinetes de recreo y lugares de experimentación del deleite visual -desde hoteles como el Roma, hasta almacenes de importación como los de Fussoni \& Maveroff-. ${ }^{2}$ Tales sitios oficiaron de escaparate para la promoción y popularización de experiencias directas con imágenes, acontecimientos -tanto sociales como individuales- tendientes a generar nuevas prácticas visuales entre los "curiosos" porteños. Dentro 
de este marco de ampliación de la visualidad, aquellos sitios estimulaban "mirar el mundo moderno en su multiplicidad de aspectos" (Telesca y Amigo, 1997, p. 33). En suma, se trataba de una sociedad que con avidez icónica, consumía todo tipo de productos visuales: desde el estereoscopio a los panoramas, pasando por las vistas de ciudades y los dioramas, además de los álbumes, las tarjetas de visita-carte-de-visite-, las ilustraciones o las más "tradicionales" exposiciones pictóricas, en las cuales se gozaban "otras impresiones y se la pasa bien, una media hora" (La Tribuna, 11/5/1859).

Contemplada panorámicamente, se trata de una época caracterizada por la expansión del capital, el ansia de conexión, la circulación de información y las comunicaciones globales (Osterhammel, 2015, p. 1000). Se asiste a tiempos de consolidación de los ideales de una cultura burguesa (Gay, 1992) en que lo moderno y sus sentidos derivados -tecnología, progreso, novedades- encuentran profundo calado en las sociedades, configuradas sobre una raíz común: el fenómeno de "unificación del mundo" (Hobsbawm, 2006 [1975]). En el plano local, se configura una atmósfera modelada por un "acuerdo civilizatorio" entre las elites dirigentes, basado en la confianza sobre los instrumentos modernizadores como agentes de progreso (Sabato, 2012, p. 100). En consonancia, se delinea una sociedad dinámica y cambiante que promueve la apertura al mundo, presta a la incorporación de novedades. A modo de ejemplo y como explica Caimari (2016), si miramos el caso de Buenos Aires en relación con la primicia del sistema de cable submarino (1866), debe considerarse a aquella como una sociedad geográficamente distante de los centros de noticias internacionales pero con un "apetito voraz" por las noticias mundiales. Y es precisamente esta favorable predisposición lo que permitiría explicar esa "ansiedad" por el inminente acceso al mundo (Caimari, 2016, pp. 611-612).

Esta apertura de la ciudad a un sistema global trajo consigo numerosas implicancias, entre las cuales destacan la incorporación de tecnologías que, como la fotografía, modificarían radicalmente los dominios del ecosistema visual urbano. En efecto, desde finales de la década de 1850 y durante el decenio siguiente es posible advertir una auténtica proliferación de soportes y medios tecnológicos que contribuyen al progresivo trastocamiento de aquel universo. Por un lado la fotografía daba sus primeros y decisivos pasos, tanto con la explosión de las carte-de-visite(Alexander, 2009, p. 13), como con el abaratamiento de los costos de reproducción -con la introducción del ferrotipo y el papel albuminado-(Amigo, 1999, p. 45). Tales factores actuaron sinérgicamente en la circulación de variedad de imágenes, entre ellas Recuerdos de Buenos Ayres, primer álbum fotográfico publicado en 1864 por Esteban Gonnet (Gonnet, 1864), concebido con una visión modernizadora (Alexander, 2009; Masán, 2017). Por otra parte la litografía continuaba extendiéndose con acentuada intensidad, ${ }^{3}$ al tiempo que las ilustraciones en general y las caricaturas en particular, se inscribían como apremiantes protagonistas de una forma de abordaje crítico de la realidad.

Esta renovación de técnicas y procedimientos, así como la extensión de la fotografía, la litografía, la caricatura, los dispositivos ópticos, las performances visuales, la pintura y la prensa gráfica contribuyen a construir un significativo posicionamiento de lo visual, modelando una atmósfera estimulante para la generación de diversas experiencias icónicas. Tamaña pluralidad supone igualmente una indagación por parte de los consumidores, quienes empleaban diferentes estrategias para encontrar en los acontecimientos icónicos ya sea información, placer o experiencias novedosas que permitieran satisfacer su cada vez más excitada curiosidad.

Visto de un modo general, mientras la cultura visual se amplía y complejiza como nunca hasta entonces, el terreno de las publicaciones periódicas experimenta también relevantes mutaciones. En sintonía con la diversidad reinante, es posible advertir una creciente cantidad de impresos de carácter periódico, entre las cuales podemos destacar la segunda época de la Revista del Plata (del ingeniero saboyano Charles Henry Pellegrini en 1861), La Revista de Buenos Aires (creada por los abogados Miguel Navarro Viola y Vicente Quesada en 1862), El mosquito (fundada por Henry Meyer en 1863), el Correo del Domingo (impulsada por José María Cantilo en 1864), los Anales de la Sociedad Rural Argentina (dirigida desde 1866 por Eduardo Olivera), La Revista Argentina (erigida en 1868 José Manuel Estrada), la Revista El Progreso (de carácter masónico, fundada por el abogado español Miguel Roig en 1869), la Revista del Archivo General 
de Buenos Aires (promovida por Manuel Trelles en 1869) o la Revista de Legislación y jurisprudencia (promovida en 1869), por citar ejemplos notorios y heterogéneos del período. Si bien cada una de ellas asume distintos perfiles -formales, editoriales y de público-, persiguen distintas finalidades y mantienen existencias dispares, se acentúa un carácter clave del mercado editorial: la "compartimentación" del público lector, con publicaciones que lentamente comienzan a buscar nichos específicos de consumidores, ya sea por temáticas, géneros o tipos de informaciones. Finalmente, en el contexto político descripto la prensa asume una importante función en la constitución del incipiente Estado Nacional, con una "misión" que estaba "vinculada a una idea iluminista y civilizatoria", inscribiéndose como una "marca indeleble de la modernidad" (Garabedian, Miranda y Szir, 2009, p. 15).

En paralelo a estos procesos se asiste a una manifestación que también marcará el pulso de un proceso que se acentuará posteriormente: el reporte visual de eventos noticiosos. Se trata de una nueva modalidad híbrida -noticia ilustrada-, la cual "por diversos motivos y con distintos rasgos, emergió en Buenos Aires en la década de 1860", tratándose de una conjunción entre sucesos de actualidad e iconografía, en un marco donde la prensa periódica "le asignó a lo visual un espacio destacado y se constituyó en un fenómeno de valor cultural significativo" (Szir, 2013). Esta convergencia entre visualidad y prensa posibilita que la imagen vaya adquiriendo mayor protagonismo en algunas publicaciones, en buena medida producto de las transformaciones culturales referidas, así como la difusión de nuevas tecnologías que permiten ampliar el horizonte de posibilidades dentro del ámbito gráfico. De estas orientaciones y construcciones de sentido nos encargamos a continuación, penetrando en la trama de algunas iconografías en el $C D$ y $E M$.

\section{El Correo del Domingo y El mosquito, entre lo micro y lo macro}

El Correo del Domingo ha sido abordado por distintos autores (Auzá, 1980; Giunta, 1994, 2002 y 2006; Szir, 2009 y Roman, 2010), quienes han remarcado el carácter pionero que asumió en tanto publicación encargada de difundir las letras -nacionales y extranjeras-. Recuperando lo expuesto por Giunta -quien atiende a las representaciones de ciudad que se desprendían de sus páginas, especialmente de la pluma de su director José María Cantilo-, dicha publicación se constituye como un sitio desde el cual se hacía énfasis en la urbanidad de Buenos Aires a partir del impacto de la industrialización (Giunta, 1994), llegando incluso a inscribirse como uno de los primeros intentos de conceptualización de lo "moderno" (Giunta, 2006, p. 14). A esta novedad conviene agregar otro rasgo notable: el CD fue uno de los primeros periódicos que desplegó el "registro de actualidad ilustrada, acompañado con otros contenidos" (Szir, 2013), como una tentativa de reportar visualmente eventos noticiosos.

El caso de El mosquito resulta también singular, pues aunque no inauguró la prensa satírica ilustrada en nuestro país, si fue el primero que tuvo gran difusión y continuidad en Buenos Aires (Roman, 2017). Considerando que existe mayor volumen de trabajos que se encargan del análisis de este último, ya sea para rescatar su naturaleza facciosa (Cibotti, 1993; Matallana, 1999) o su costado crítico (Cavalaro, 1996; Ogando, 2000), o bien como un escenario de convergencia político cultural (Gionco, 2016; Roman, 2010 y 2017), es posible advertir en estos una tendencia a complejizar no sólo el papel otorgado a las imágenes sino también la arena en la cual esta publicación se insertó. Es posible advertir no obstante una tendencia a orientar los exámenes durante los años dorados de EM bajo la dirección de Henry Stein, siendo igualmente notorio que el trabajo efectuado por el francés Henry Meyer -dibujante y fundador de la publicación- durante la primera etapa de la publicación satírica ha recibido mucha menos atención. En virtud de ello también intentaremos penetrar en aquellos orígenes, situando sus testimonios iconográficos -realizados no sólo en esta publicación, sino también en el CD- como acotados fragmentos de un "ojo de época" (Baxandall, 1978, pp. 58-60). 


\section{2. a. Modificaciones y ausencias}

Estudiar el carácter visual de estas publicaciones implica examinarlas "no sólo por su valor estético sino también por su sentido y su capacidad de definir experiencias visuales en un contexto histórico particular" (Szir, 2016, p. 60). Siguiendo esta premisa, un primer acercamiento a las mismas nos ofrece una serie de rasgos particulares: el $C D$ pensado como un periódico que ofrecía distintos tipos de géneros literarios, de diversas procedencias y con la frecuencia dominical que su nombre indica. EM en cambio, orientado a la sátira y la burla de la política y la sociedad doméstica.

El primer detalle que destaca en ambas es el hecho de que se presenten a sí mismas como "periódicos ilustrados", razón por la cual le confieren desde lo discursivo -y como veremos también desde lo material- a la imagen un sitial destacado. En base a esta huella, observamos otra característica distintiva: conforme se van desarrollando a lo largo del tiempo, y en sintonía con lo que parecen ser las exigencias sociales crecientes de imágenes, ambas experimentan variaciones significativas en sus portadas, volviéndose más pregnantes desde el punto de vista icónico (Figura 1. Portadas).

FIGURA 1

Portadas
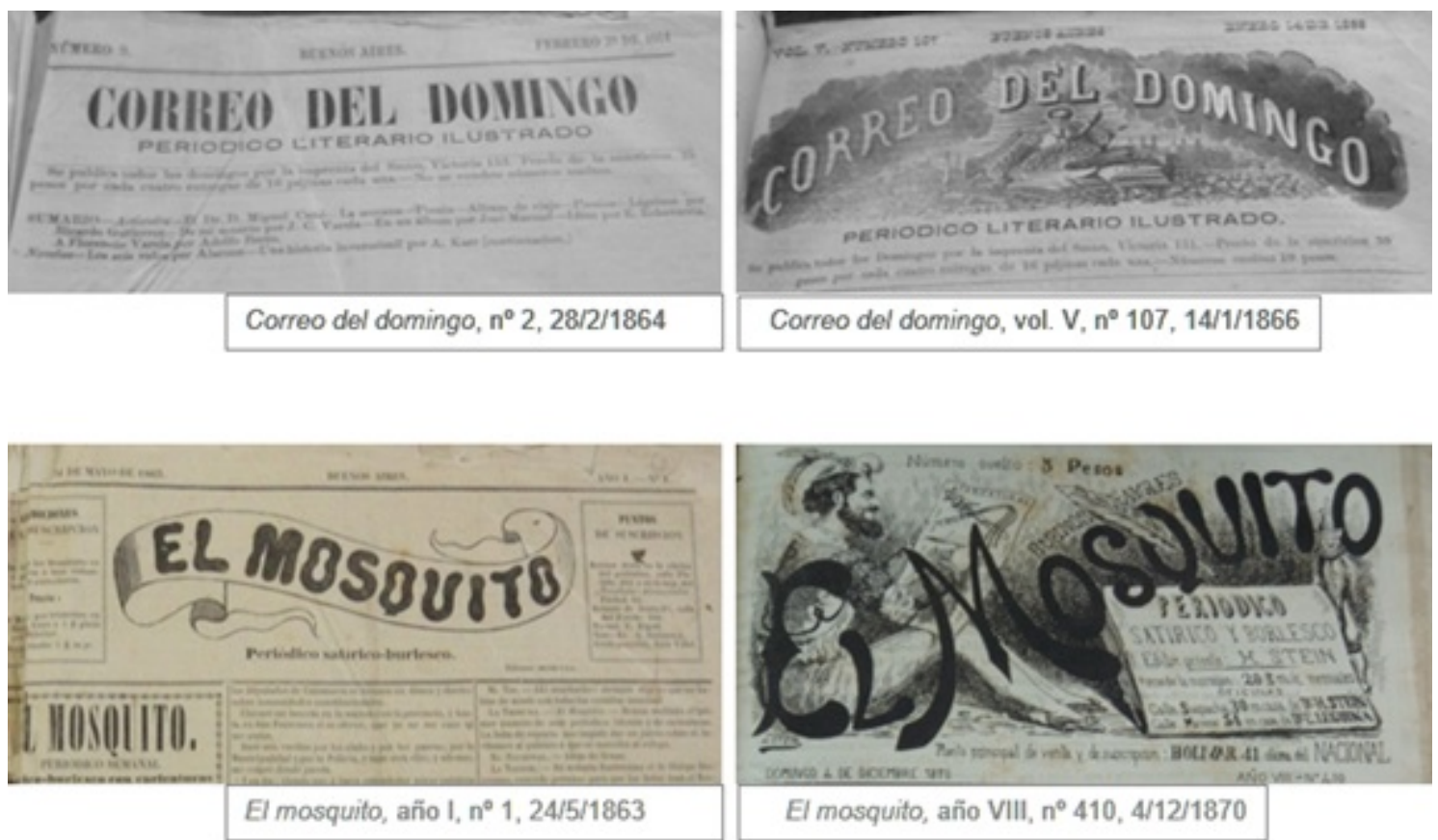

Mientras que $E M$ realiza una paulatina modificación de su frontispicio, en el caso del $C D$ el traspaso se efectúa abruptamente en la semana del 10 al 17 de julio de 1864, entre los números 28 y 29 ( $C D$, n. ${ }^{\circ} 28$, 10/7/1864 y $C D$, n. $\left.^{\circ} 28,17 / 7 / 1864\right)$.

Estas alteraciones, las cuales responden a variables técnicas -como las mejoras en las modalidades de impresión y la incorporación de nuevas tipografías y recursos gráficos-, también ofrecen rastros respecto a la avidez icónica de aquella sociedad. Lo expuesto se refuerza si lo cotejamos no ya con las presencias sino con una ausencia: las jornadas en que ambas publicaciones se vieron imposibilitadas de ofrecerle a sus lectores las correspondientes ilustraciones, el 24/3/1864 el CD, y el 3/5/1868 EM (Figura 2. Ausencias). 
FIGURA 2

Ausencias

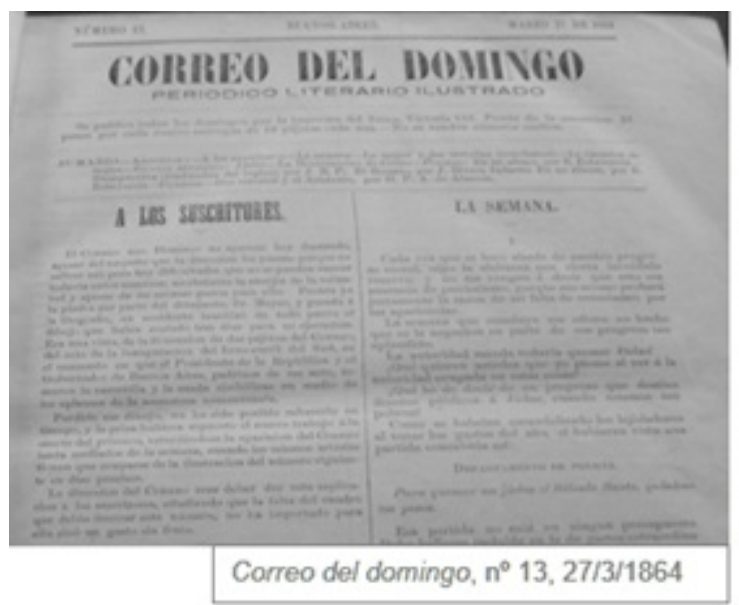

PRESENTAMOS NUESTRA DISCULPA A LOS SUS. CRITORES DEL MOSQUITO

UNA DESGRACIA HABTIENDONOS

SUGEDIDO EN LA GARTCATURA,

NO PODEMOS REMEDIAR SIN

ATBAZAR EL PERIODico.

El Masquito, año V, $n^{\circ} 276,3 / 5 / 1868$

Resulta particularmente jugosa la explicación de este episodio efectuada en el $C D$, permitiendo asomarnos a los entresijos de la producción de imágenes de entonces. La dirección del periódico señala que:

El Correo del Domingo no aparece hoy ilustrado, a pesar del empeño que la dirección ha puesto porque no saliese así; pero hay dificultades que no se pueden vencer todavía entre nosotros, no obstante la enérgica de la voluntad y a pesar de no escusar gastos para ello $\left(C D\right.$, n. $\left.^{\circ} 13,24 / 3 / 1864\right)$.

La explicación de tan lamentable acontecimiento se hace en los siguientes términos: "Pronta ya la piedra por parte del dibujante, Sr. Meyer, y pasada á la litografía, un accidente inutilizó de todo punto el dibujo que había costado tres días para su ejecución" ( $C D$, n. $\left.{ }^{\circ} 13,24 / 3 / 1864\right)$. Luego de describir la trunca iconografía una vista de la inauguración del Ferrocarril del Sud, con presencia de la comitiva gubernamental- se evaluaba que:

Perdido este dibujo, no ha sido posible rehacerlo en tiempo, y la prisa hubiera espuesto el nuevo trabajo á la suerte del primero, retardándose la aparición del Correo hasta mediados de la semana, cuando los mismos artistas tienen que ocuparse de la ilustración del número siguiente en días precisos $\left(C D, \mathrm{n} .^{\circ} 13,24 / 3 / 1864\right)$.

Finalmente concluyen la aclaración con una referencia de talante económico: "La dirección del Correo cree deber dar esta explicación a los suscriptores, añadiendo que la falta del cuadro que debía ilustrar este número, no ha importado para ella sino un gasto sin fruto" (Correo del Domingo, n. ${ }^{\circ} 13,24 / 3 / 1864$ ).

Aunque desconocemos más detalles sobre aquellos eventos, estos accidentes -los cuales no son los únicos, aunque si los primeros- en las páginas de las publicaciones, tanto como las actitudes adoptadas por sus editores ante tal ausencia, nos permiten entrever la importancia de la iconografía al punto de "deber dar una explicación" o "presentar disculpas" ante los lectores. Conviene apuntar que las razones esgrimidas implican, en ambos casos, una motivación de carácter temporal: la inconveniencia de "retrasar" la salida de la publicación.

Considerando estos indicios que acentúan el protagonismo que adquiere lo visual y su relación con la premura, nos adentramos en las particularidades de algunas de las ilustraciones, como un modo de sumergirnos en sus entretelones.

\section{2. b. Una mirada compleja}

Si hasta aquí pusimos de relieve la notoria importancia de lo visual y la jerarquización de las imágenes, también es posible detectar una complejización de las mismas, en sintonía con los tiempos vertiginosos a los que por 
entonces se asistía. En primer término, lo icónico comienza a dar cuenta de modo más o menos dramático, de algunos episodios con tenor sensacionalista, como un choque de trenes en el camino del oeste o el lúgubre paisaje del "momento" en que un huracán azotó la zona de San Isidro (Figura 3. Sensacionalismos).

\section{FIGURA 3}

Sensacionalismos
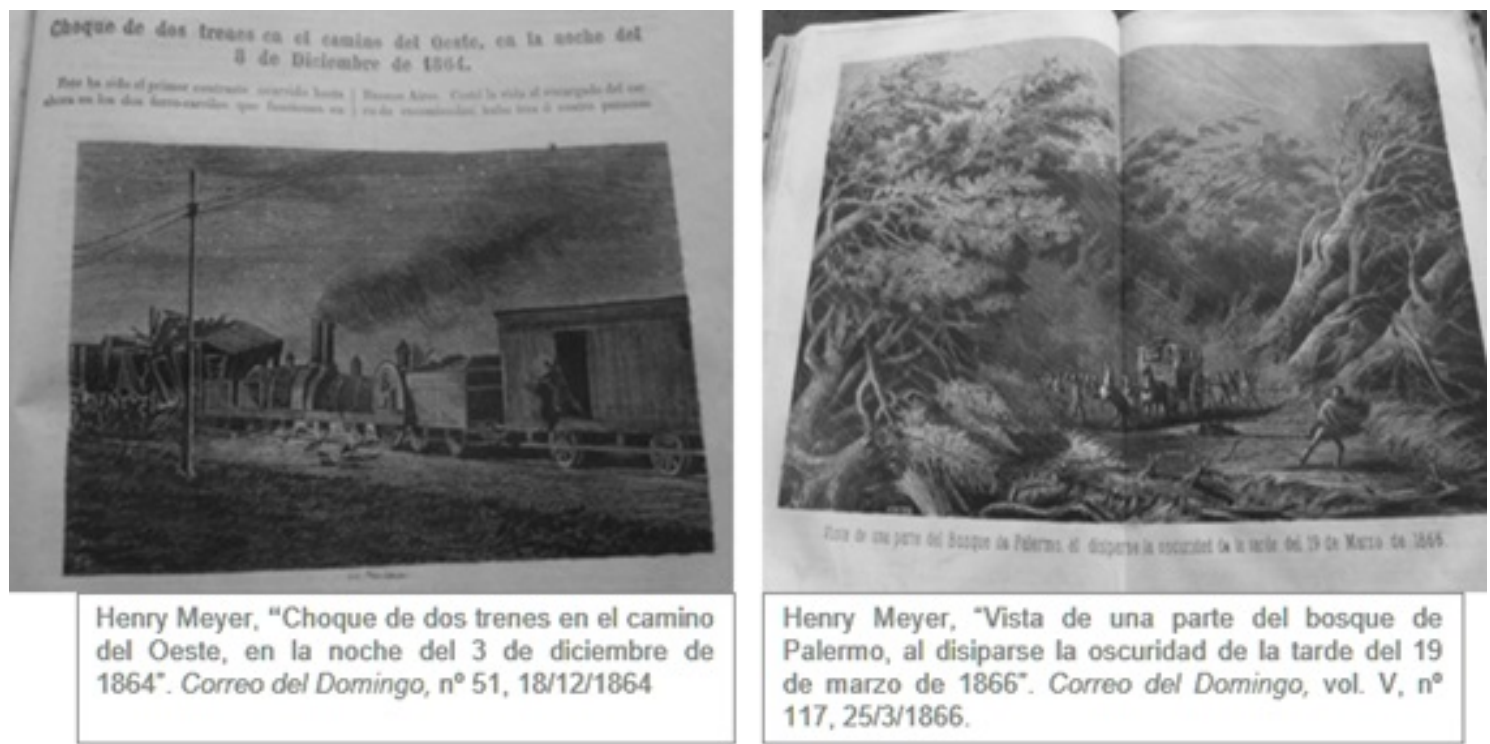

Resulta sugerente evaluar la convivencia entre la pretendida "instantaneidad" de estas imágenes que registran precisamente el "momento", con las condiciones antes expuestas respecto a la factura de la litografía, en tanto técnica de reproductibilidad aplicada al desarrollo de la prensa.

Observando el conjunto de las iconografías se nos presenta una nota aún más intrigante que revela un universo más abigarrado que el de la relación temporal -de por si sumamente compleja- de estos registros. Como veremos en los siguientes ejemplos, en muchas de las imágenes producidas por Henry Meyer -tanto para $E M$ como para el $C D$ - será posible apreciar una modificación de escalas que conviven solapadamente en las páginas de estas publicaciones: desde lo global e impersonal de la construcción cartográfica, a la intimidad del retrato o la caricatura -tanto de personajes locales como foráneos-; de lo pintoresco de un cuadro de costumbres, al detalle de un mapa del posicionamiento de tropas durante la Guerra del Paraguay; de la visión panorámica de una escena de batalla, al detalle pormenorizado en los rasgos de algún individuo caricaturizado (Figura 4. Mirada abigarrada). 
TIGURA 4

\section{Mirada abigarrada}
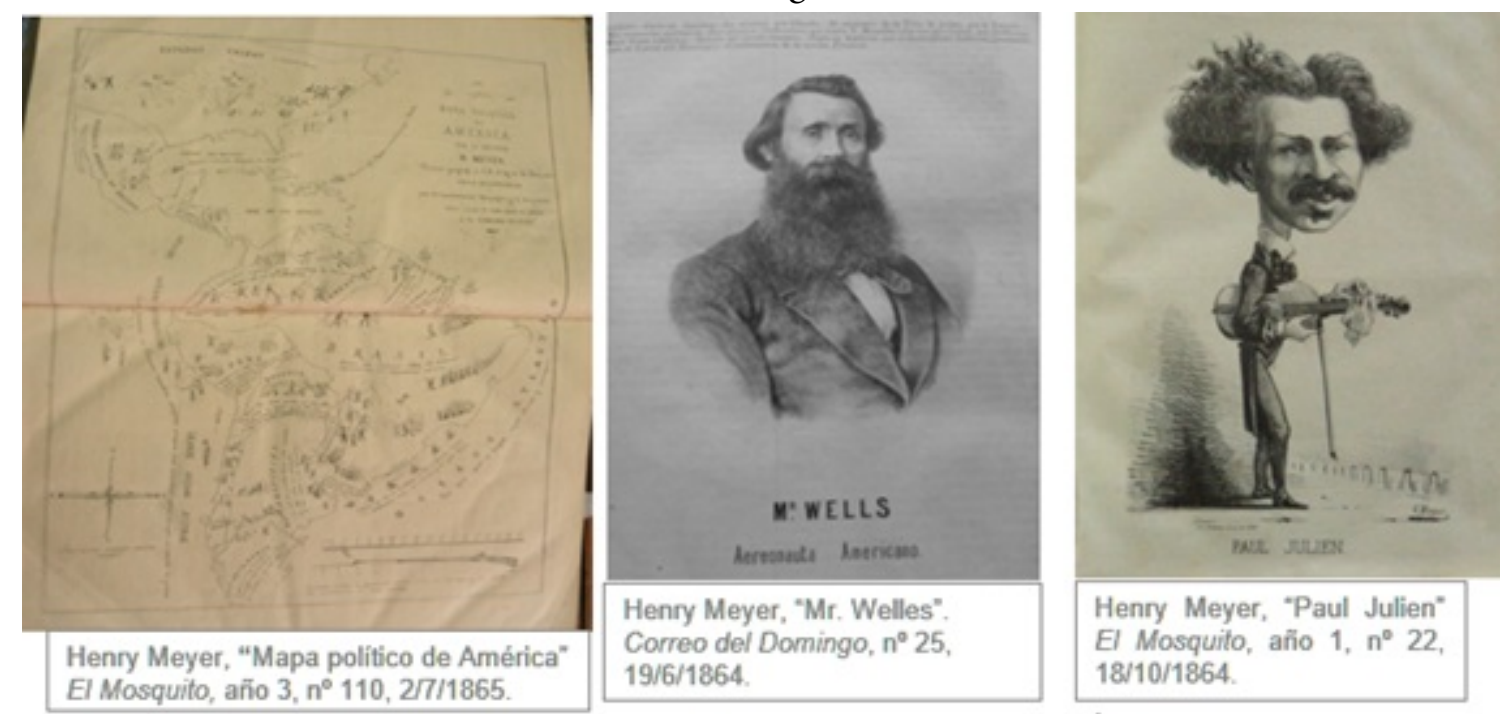

Henry Meyer, "Paul Julien" El Mosquito, año $1, n^{\circ} 22$, 18/10/1864.
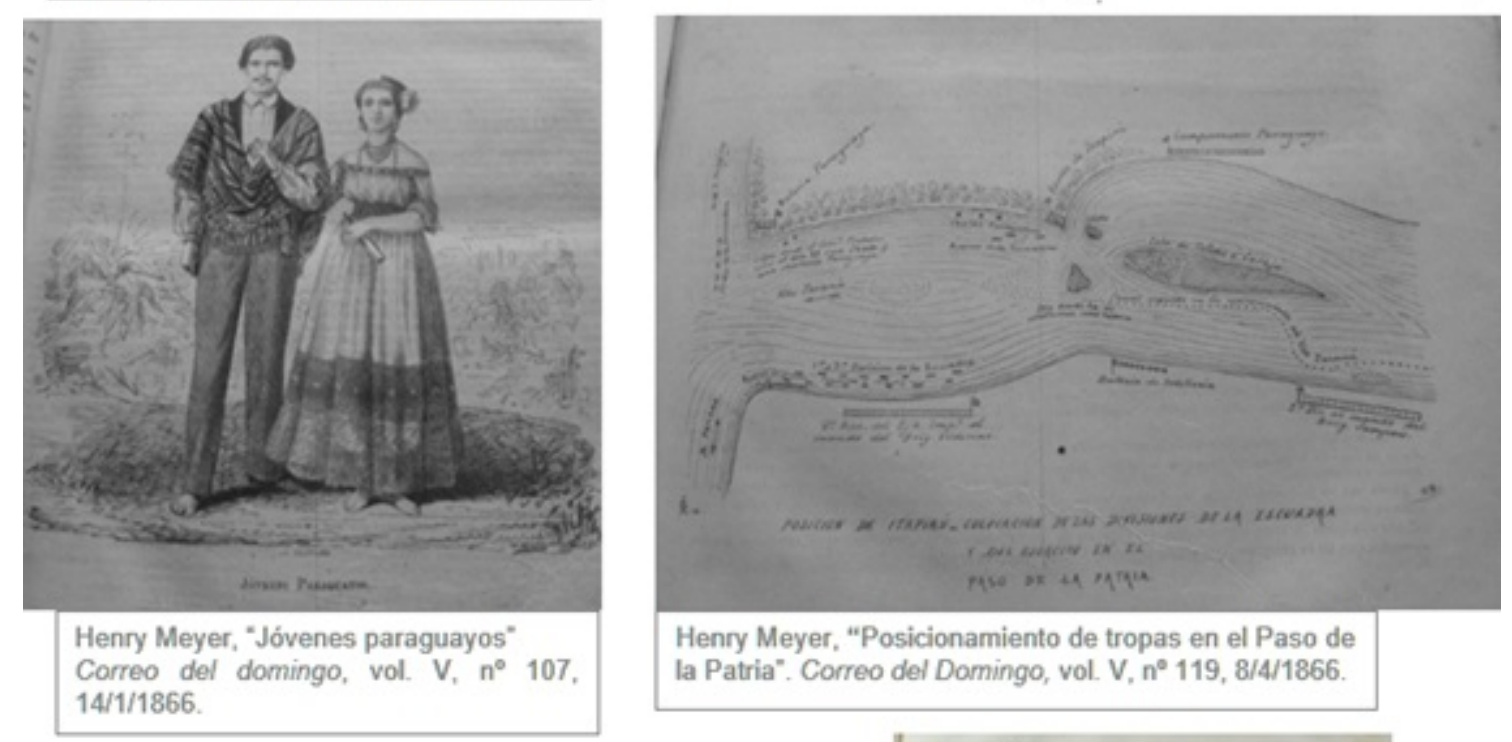

Henry Meyer, "Posicionamiento de tropas en el Paso de la Patria". Correo del Domingo, vol. V, $\mathrm{n}^{\circ} 119,8 / 4 / 1866$.
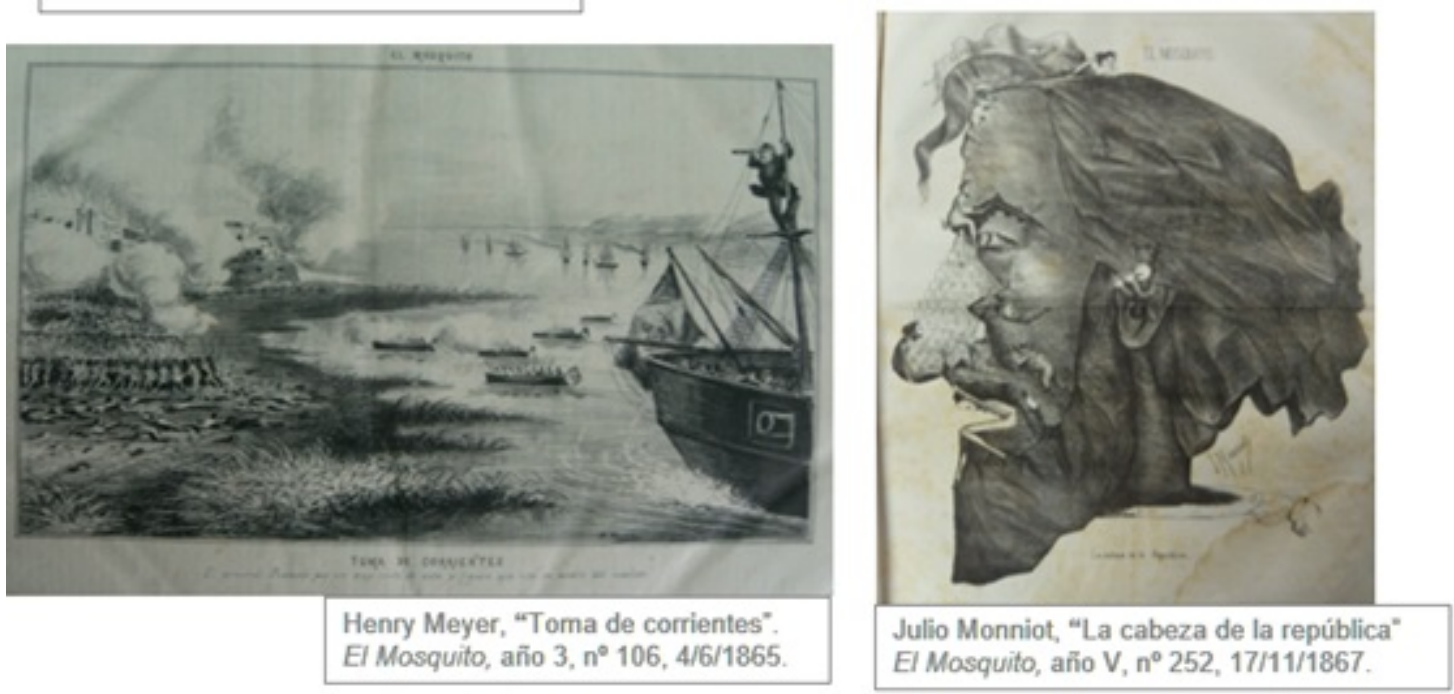
Si bien es cierto que el desarrollo de la Guerra del Paraguay (1865-1870) contribuyó a la proliferación de imágenes sobre los campos de batalla y el movimiento de tropas -principalmente en el $C D$, aunque no únicamente- (Roman 2010, p. 287), conviene remarcar que la presencia del elemento visual constituía novedosos estímulos que instaban a la lectura atenta y detallada de tales iconografías. Esta amplificación de la visión y de lo visible se hace presente también en otros atributos, como la incorporación de dispositivos que permiten "modificar" la mirada. Así es posible advertir numerosas incorporaciones de distintos instrumentos ópticos: desde telescopios a catalejos (Figura 5. Horizontes), pasando por anteojos, lupas e incluso una linterna mágica (Figura 6. Horizontes II).

FIGURA 5

Horizontes I

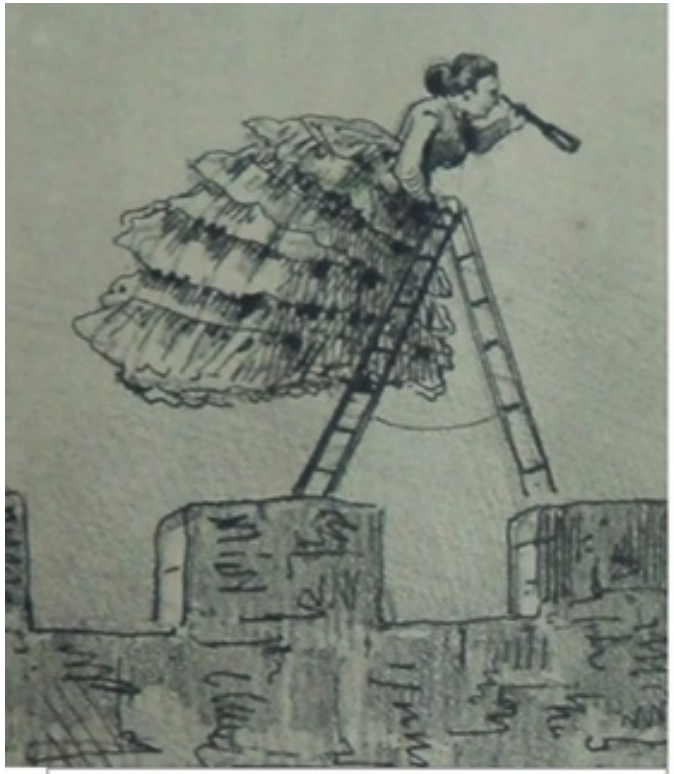

Henry Meyer, "Canción fúnebre de pareja" (detalle) El Mosquito, año III, $n^{\circ} 138,14 / 1 / 1866$.

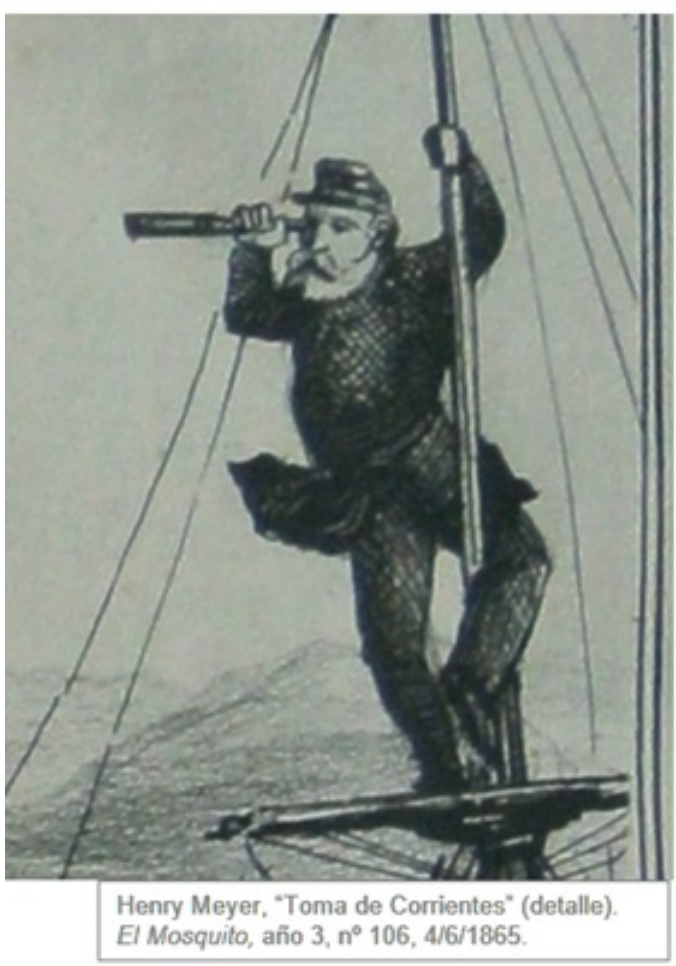

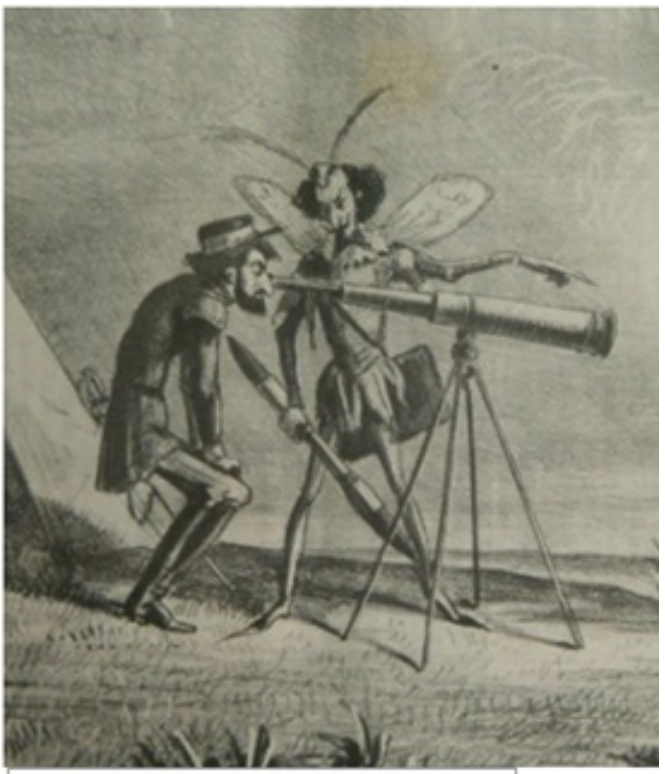

Henry Meyer, "Actualidades" (detalle) El Mosquito, año III, $n^{\circ} 112,16 / 7 / 1865$.

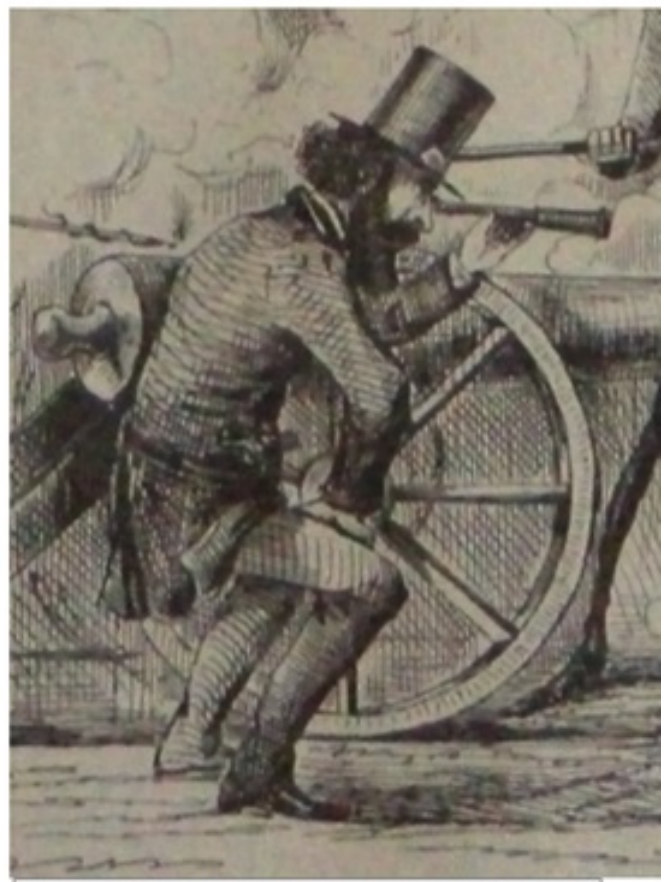

Henry Meyer, "Próximas elecciones" (detalle) El Mosquito, año $1, n^{\circ} 30,26 / 12 / 1863$. 
FIGURA 6

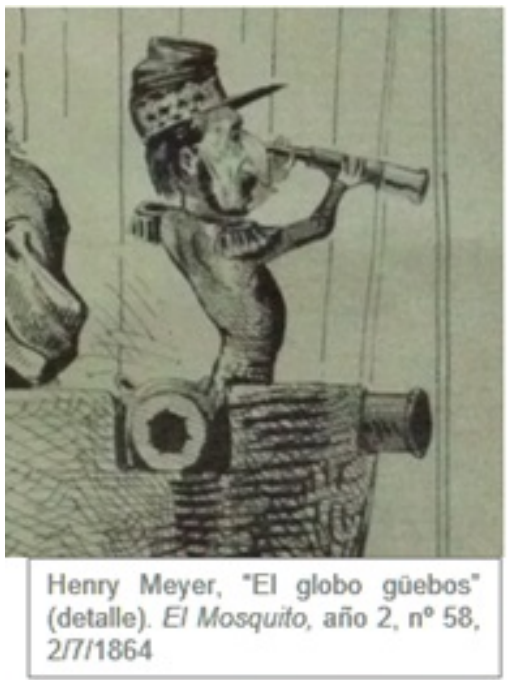

Horizontes II

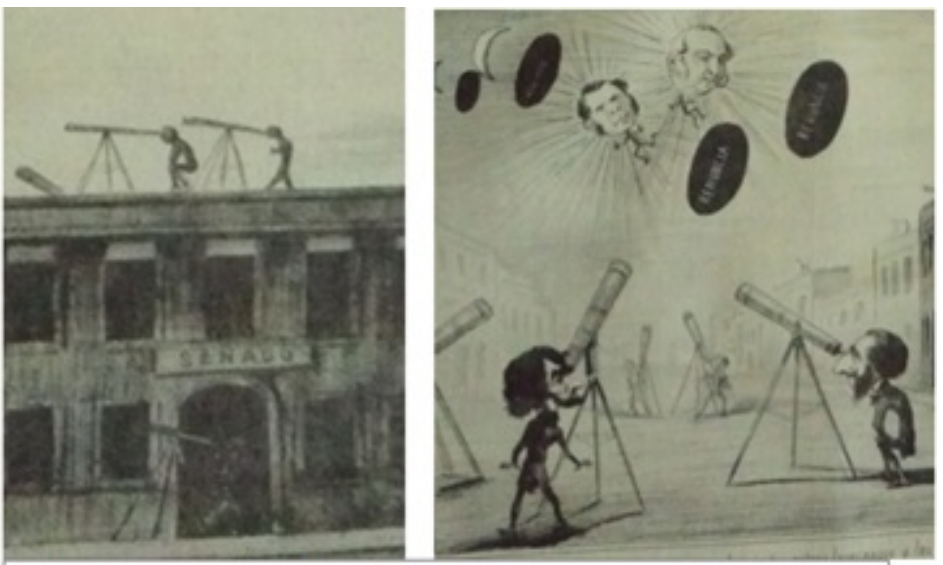

Henry Meyer, "El mosquito" (detalle) El Mosquito, año 1, n50, 7/5/1864
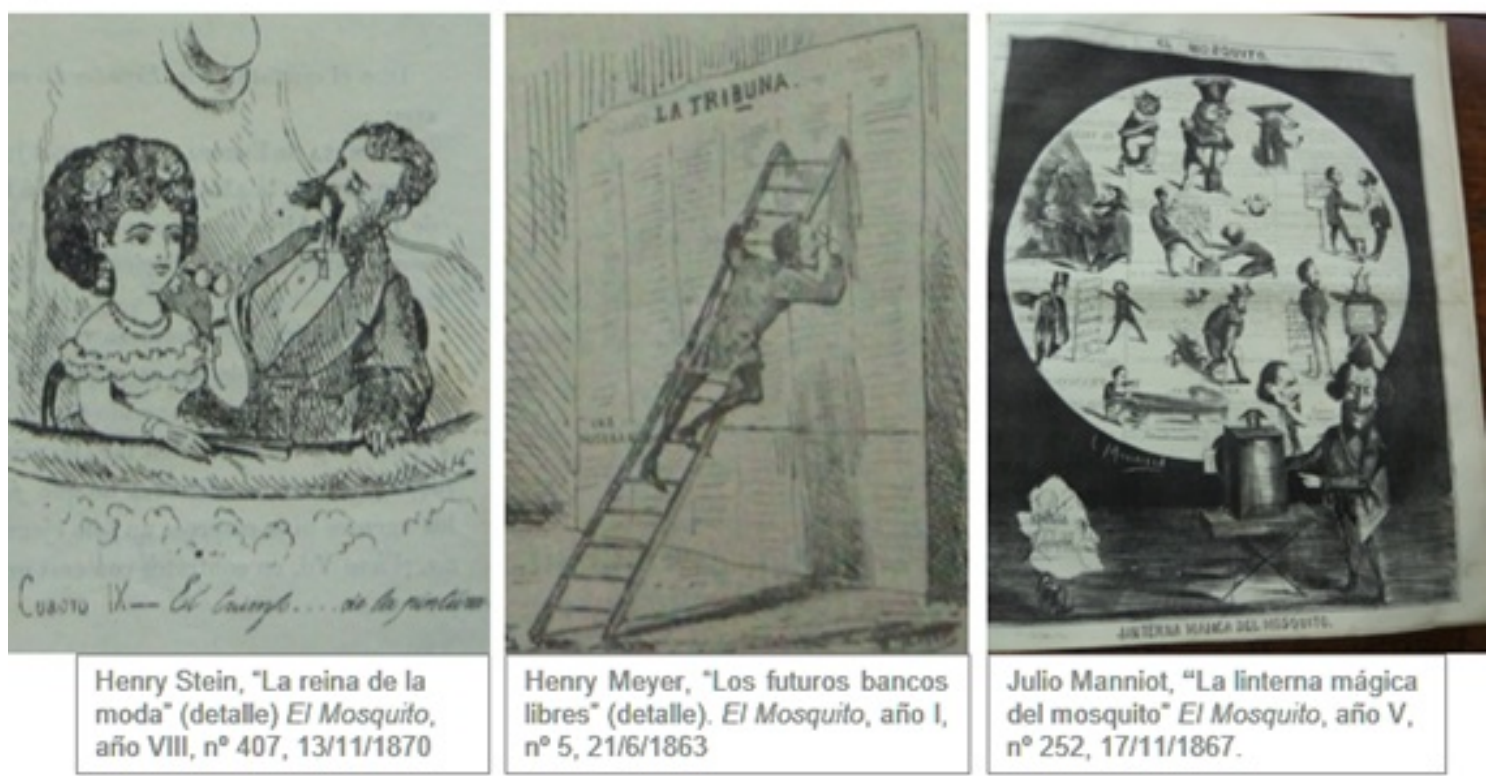

Julio Manniot, "La linterna mágica del mosquito* El Mosquito, año V. $n^{\circ} 252,17 / 11 / 1867$

Estas inclusiones evidencian no sólo un panorama respecto de la importancia conferida a lo visual, sino que también nos marcan el pulso de un contexto cultural caracterizado por una avidez icónica, la cual posibilita, estimula y promueve -exige, podríamos decir- ver de un modo diferente. En parte posibilitadas por las novedosas "máquinas de mirar" (Díaz-Duhalde, 2014), estas modalidades implican también un reposicionamiento del observador, gestionando visualmente el entorno desde una multiplicidad de perspectivas: viendo más lejos, con mayor proximidad, con amplitud o de modo más nítido. En síntesis: mirar de una manera moderna.

Tales referencias, observadas como un mosaico complejo, nos permiten interrogarnos acerca de los horizontes de esta sociedad con ansias de mundo, concretamente en lo referido a sus concepciones espaciales. Intentando situar estas imágenes en un contexto más fatigado y adentrarnos un escalón más en estas preocupaciones escópicas, nos detendremos en otro tipo de iconografías contemporáneas, precisamente aquellas que aluden al espacio. 


\section{SOLAPAMIENTOS ESPACIALES: AMPLIFICACIONES Y PARTICULARISMOS.}

Dentro de las configuraciones que asumen los modos de ver de los habitantes porteños en el marco de una emergente modernidad, la nueva sensibilidad puede ser concebida como una gestión pendulante entre dos extremos: lo amplificado-general por un lado, y lo detallado-singular por otro. Si efectuamos un breve panorama sobre los relevamientos geográficos realizados durante este contexto, veremos dos valiosos ejemplos que sugieren análogos procedimientos: mientras se realiza el catastro más pormenorizado que haya conocido la ciudad hasta entonces -el denominado Catastro Beare, ejecutado entre 1860 y 1870-, cobra forma también la proyección cartográfica hasta ese momento más precisa del territorio bonaerense (1864), organizada en base a los datos recolectados por el Departamento Topográfico. ${ }^{6}$ Observados en clave comparada (Figura 7. Espacios) y en vínculo con lo expuesto, es posible detectar una concordancia en relación a las imágenes referidas del $C D$ y $E M$.

FIGURA 7

Espacialidades
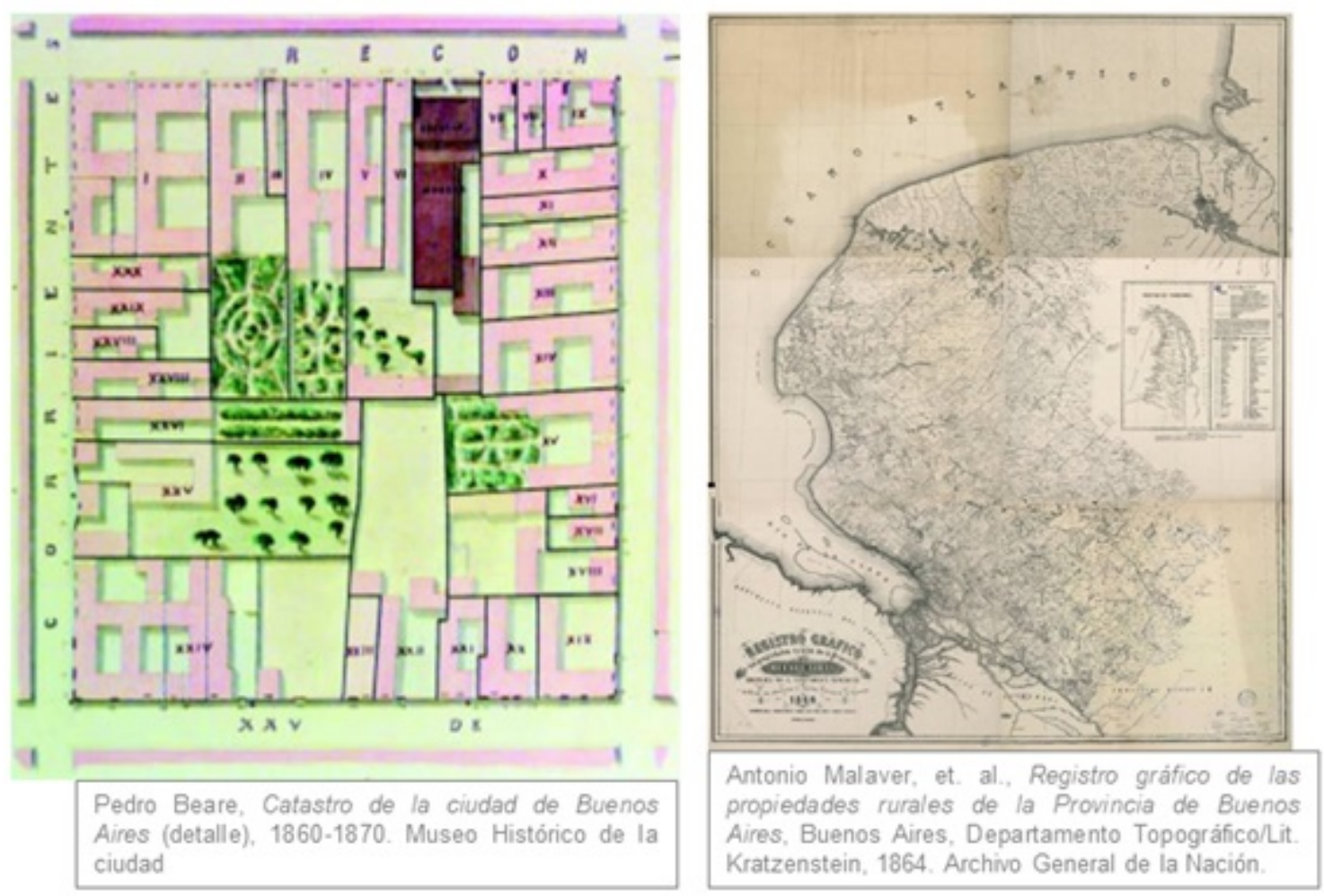

Las resonancias de estas proyecciones resultaron singulares, a juzgar por las expectativas creadas respecto al Registro gráfico de 1864. En palabras de Antonio Pillado (1864) se trató de un "verdadero plano topográfico", consignado con "todos los datos (...) reunidos durante cuarenta años" y "compulsados con la mayor prolijidad" (Pillado, 1864, p. 193). El autor del Diccionario de Buenos Aires evaluaba el Registro poniendo de relieve la "exactitud" de la "medición", la cual garantizaba el "resultado científico" de la construcción. Esta carta geográfica nos provee además otro indicio respecto a la variación y amplitud de aquellas miradas, como muestra la perspectiva orientada hacia el Sur. Según juzgaba el propio autor esta orientación revestía un carácter medular, y así lo refiere en carta enviada al director del $C D$ el 12 de abril de 1865, donde explicaba detalladamente las razones de esta "variación" cartográfica: 
(...) este no es un error, sino para aquellos que están acostumbrados á los planos de Europa y no tienen el criterio suficiente para discernir la necesidad de una orientación distinta en un hemisferio diverso; pero como el plano representa una parte del hemisferio del sud, tenemos el polo del sud elevado sobre el horizonte, razon natural para que levantemos la cabeza si queremos al sud $\left(C D\right.$, n. $^{\circ} 69,23 / 4 / 1865$, p. 269).

La metodología no se circunscribe ni se agota a un evento aislado como este plano - tan detallado como exhaustivo-, sino que esta aparente ampliación de horizontes llevará a que dos años después el Departamento Topográfico edite la Carta Geográfica de la Provincia de Buenos Aires (1866), en la cual se incluirá una particularidad que refuerza lo explicitado: la alusión directa al "desierto" patagónico, ubicado en las lejanas geografías del sur (Figura 8. Territorios).

FIGURA 8

Territorios

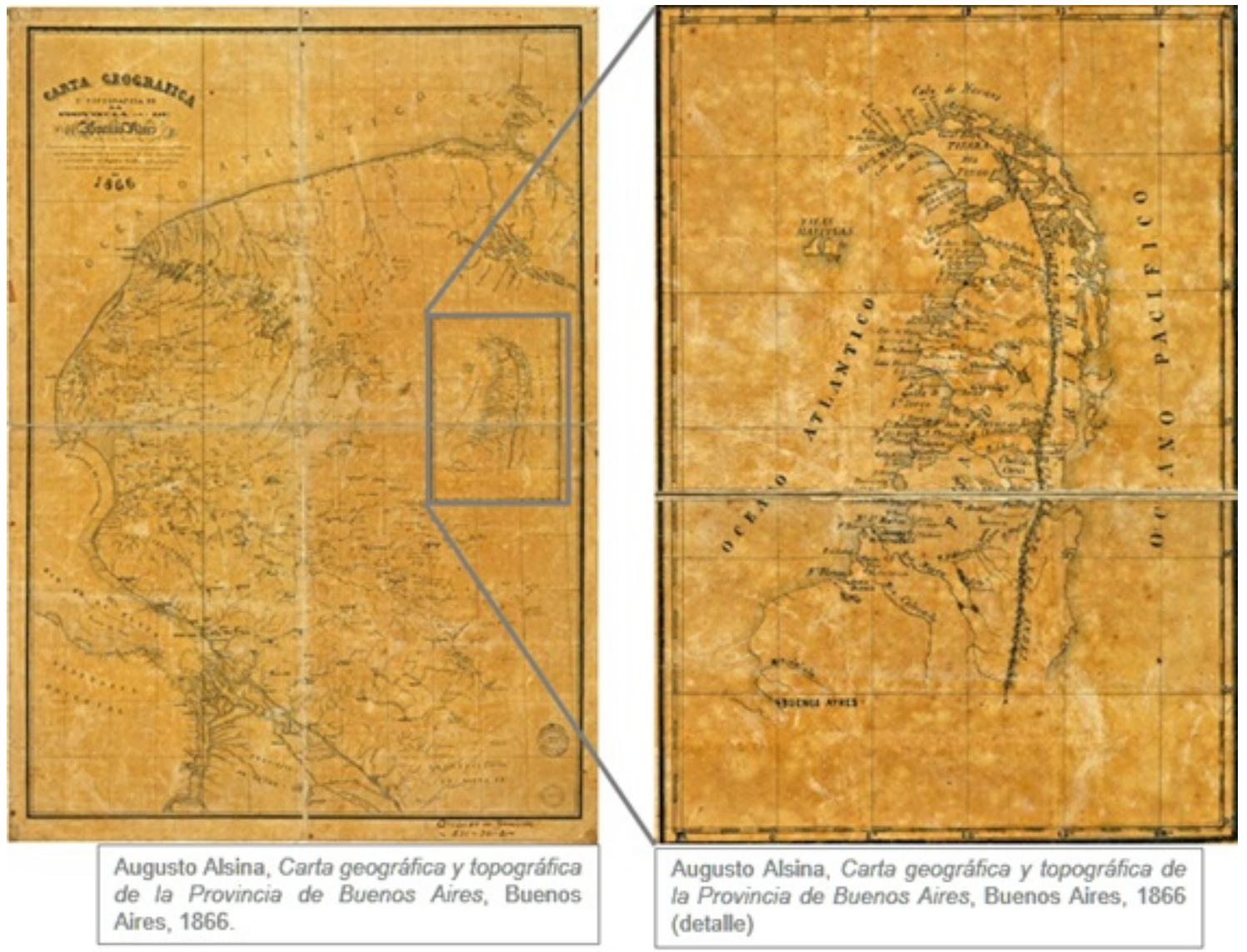

Lo que consideramos relevante de estos ejemplos no descansa en la acción de la mensura per se-actividad que por otra parte se realizaba ya desde finales del siglo XVIII-, sino en el estilo visual que asume la misma y con la cual se presenta. Destaca asimismo la coexistencia de escalas dispares en un mismo marco temporal y geográfico como la ciudad, desde el detalle de Beare a la referencia del territorio bonaerense en su conjunto y también incluso el patagónico. Independientemente de las condiciones de necesidad sociopolítica -que desde luego motorizaron con cierto apremio estas representaciones- para un Estadonación en construcción, destacamos las convergencias visuales entre estos documentos y las evidencias icónicas previamente examinadas.

Vistos en conjunto, estos repartos iconográficos ofrecen pistas respecto a un ambiente visual no sólo ampliado sino también abigarrado, en el cual se presentan simultáneamente diversas perspectivas: como si fuera urgente ver más lejos y de cerca, lo grande y lo pequeño, lo inconmensurable y lo minúsculo. 
No resultan casualidades, y así parece rubricar Juan María Gutiérrez -asiduo colaborador del $C D-$, al destacar la importancia dada a lo microscópico y lo invisible a simple vista en el examen por ejemplo, de una gota de agua:

Si ahora que tenemos algunas nociones acerca de la constitución de los cuerpos, examinamos otra vez una gota de agua, ya no nos espondremos á solo ver en ella una masa inerte; antes por el contrario, ese pequeño globulillo, se presentará á nuestra inteligencia como una constelación formada de astros, cada vez más diminutos, jirando con una velocidad incapaz de ser advertida por nuestros sentidos (...) (CD, 16/9/1866, p. 159).

Concluye señalando que "Los sistemas infinitamente grandes que jiran majestuosamente en los espacios del cielo, se reproducen en miniaturas infinitamente pequeñas al alcance de nuestra mano, bajo las leyes de la misma pasmosa armonía" (CD, 16/9/1866, p. 159).

Lo invisible también cobra relevancia dentro de lo visible, y como muestran estos ejemplos se imponía una visión de la complejidad y también de lo efímero, articulada entre lo macro y lo micro, así como el mundo, la ciudad y el territorio allende las fronteras al mismo tiempo. Si "toda ciudad moderna es efímera, puesto que su renovación constante es una condición de su existencia” y esta caducidad imprime además una incertidumbre generalizada en sus habitantes (Liernur, 1992, p. 107), esta visión de lo moderno como perecedero y volátil resultaría convergente respecto al nuevo modelo escópico: la transitoriedad de los pasajes visuales que se ofrecían al público en diversos soportes - publicaciones periódicas, fotografías, obras pictóricas, litografías, almanaques, publicidades, etc.- constituyen un atisbo de aquella cualidad evanescente de la ciudad y de lo moderno, al tiempo que una sutil prefiguración de los tiempos futuros.

Comprendiendo la modernidad como una disposición "circular" o "espiral", en virtud de la cual las vidas "van y vienen entre lo próximo y lo lejano, el ayer y el hoy, el presente y el pasado" (Jiménez, 1994, p. 6), este trastocamiento espacial adquiere importancia en tanto rasgo distintivo de una ciudad que se muestra y se ve a sí misma de otro modo. Si se nos permite expresarlo con una metáfora óptica, estas imágenes que circularon en las publicaciones de la década de 1860 ofrecieron al habitante de aquella ciudad la posibilidad de calibrar su lente de diversas maneras -haciendo miradas detalladas y alejamientos, focalizando y realizando panoramas, mirando dentro de su ciudad y también allende sus fronteras- que le permitían simbólica y materialmente, ver el mundo de un modo moderno. Es decir, en su abigarrada multiplicidad.

\section{REFLEXiones FinAleS}

Este período que podríamos denominar como transicional, y durante el cual compiten imaginarios respecto a la posición y relevancia de Buenos Aires, no es plausible de ser definido como un ámbito en el cual se expande una prensa típicamente "moderna", ya que las publicaciones analizadas evidencian rasgos de antiguas formas de intercambio informativo. Si bien acelerada por los avances de los vapores, la incipiente telegrafía y el ferrocarril, an predomina una relativa lentitud en las comunicaciones -en comparación con los tiempos telegráficos de las décadas posteriores-. Por otra parte, también se advierte una preeminencia de información proveniente de Europa -principalmente Londres y París-, en desmedro de otras latitudes. Tampoco es posible hallar una "profesionalización" del rol del periodista, sino que se trata más bien de personajes caracterizados por su tendencia a la literatura.

Sin embargo la preponderancia que adquiere lo visual, sumado a la emergencia de la noticia ilustrada, la complejización de las estrategias informativas, cierta especialización de las publicaciones y los esfuerzos dirigidos al establecimiento de un público segmentado presentes en estos años, nos permiten detectar rasgos de una modernidad embrionaria. Consideramos que uno de los puntales de esta germinación radica en la configuración de una nueva sensibilidad visual, íntimamente conectada con la noción de ciudad moderna en tanto escenario de multiplicación de estímulos sensoriales, de distinta factura y tenor. En este sentido, es 
posible advertir una proliferación de elementos, prácticas y procedimientos icónicos enfocados en promover novedosas experiencias, generando una mirada dinámica del espacio, oscilante entre lo general y lo singular.

Por su propia naturaleza fractal el mundo de las imágenes nos obliga a reflexiones arborescentes. Ya por la complejidad inherente de lo icónico como del sustrato problemático de las unidades de análisis, no es posible sino ofrecer interpretaciones de estos acontecimientos visuales, incrustados dentro de "campos en disputa". Consideramos que una explicación posible de estas modificaciones en las escalas de representación puede ser enfocada desde distintos perfilamientos, conectados entre sí con una especie de encadenamiento.

Por un lado resulta notorio el complejo marco que configura al mundo por aquel entonces, modelado por un impulso conectivo que lo muestra cada vez más "unificado", convertido en un ecosistema que puede ser percibido al mismo tiempo como más grande y más pequeño. Paralelamente y atendiendo a un nivel más regional-"nacional”, son tiempos en que el país se abre y se cierra simultáneamente: apertura hacia el exterior, recibiendo y promoviendo ideas, productos, tecnologías, novedades, noticias y personas; mientras se repliega sobre sí mismo estableciendo los lineamientos que configurarán un nuevo ordenamiento político, con la consecuente edificación estatal atravesada por una doble articulación centro-periferia (Bragoni y Míguez, 2010, p. 27). Se trata también de una ciudad en la que es posible advertir dos fenómenos imbricados: uno de carácter centrípeto por el cual crea su urbanidad, reconfigurándose -espacial, material y conceptualmentede manera constante; mientras que de manera centrífuga se concibe al propio lugar como parte de un encadenamiento geográfico más amplio, construyendo, evocando y resignificando los territorios fuera de sus fronteras urbanas: ya sea de la campaña, la Patagonia o el interior, la lejana/cercana Europa, o bien dentro de un circuito cada vez más vinculado de comunicación a escala global. Resulta sintomático finalmente, otra singular yuxtaposición: al tiempo que la sociedad se amplía y crecen los espacios de sociabilidad, es posible advertir un replegamiento del individuo sobre su intimidad, marcando tensiones entre lo público y lo privado (Malosetti Costa, 1995).

Por lo expuesto, consideramos que el espíritu de estas imágenes, así como los procedimientos visuales en ella implicados y estimulados, podrían insertarse como parte de una nueva sensibilidad visual que suscribe aristas modernas: ampliada, multidimensional y solapada. Metafóricamente referido, estas imágenes constituyen una suerte de Aleph borgeano: un instante gigantesco en el cual todas aquellas posibilidades ocupan el mismo espacio, sin superposición ni transparencia, trastocadas - no sin cierta cuota de ansiedad- entre lo micro y lo macro.

\section{FUENTES CONSULTADAS}

Alsina, A. (1866). Carta geográfica y topográfica de la Provincia de Buenos Aires, Buenos Aires.

Beare, P. (1860-1870). Catastro de la ciudad de Buenos Aires. Buenos Aires. Archivo Histórico Municipal de la Ciudad de Buenos Aires.

Correo del Domingo. Periódico ilustrado, Buenos Aires, período 1864-1866. Archivo General de la Nación, Biblioteca Celesia, C-0995, C-0996 y C-0997.

El Mosquito. Periódico satírico-burlesco, Buenos Aires, período 1863-1870. Archivo General de la Nación, Biblioteca Celesia, C-4968, C-4969, C-4970 y C-4971.

Gonnet, E. (1864). Recuerdos de Buenos Ayres. Buenos Aires: Musy. Biblioteca Nacional Mariano Moreno, Fototeca Benito Panunzi.

Malaver, A. et al. (1864). Registro gráfico de las propiedades rurales de la Provincia de Buenos Aires. Buenos Aires: Departamento Topográfico/Lit. Kratzenstein. Archivo General de la Nación, Sección mapoteca, II-124.

Pillado, A. (1864). Diccionario de Buenos Aires, o sea guia de forasteros. Buenos Aires: Imprenta del porvenir. Archivo General de la Nación, Biblioteca Ernesto Celesia, C-1208. 


\section{BiBLIOGRAFíA}

Aguirre Rojas, C. (2017). Microhistoria italiana. Modo de empleo. Rosario: Prohistoria.

Alexander, A. (2009). Primeras vistas porteñas. Fotografias de Esteban Gonnet. Buenos Aires 1864. Buenos Aires: Biblioteca Nacional.

Alonso, P. (2004). Construcciones impresas. Panfletos, diarios y revistas en la formación de los estados nacionales en América Latina, 1820-1920. Buenos Aires: Fondo de Cultura Económica.

Amigo, R. (1999). Prilidiano Pueyrredón y la formación de una cultura visual en Buenos Aires. En Luna, F. (et. al). Prilidiano Pueyrredón (pp. 30-54). Buenos Aires: Banco Velox.

Auzá, N. (1980). El Correo del Domingo (1864-1868) y (1879-1880). Buenos Aires: Instituto Histórico de la Ciudad de Morón.

Baxandall, M. (1978). Pintura y vida cotidiana en el Renacimiento. Arte y experiencia en el Quatroccento. Barcelona: Gustavo Gili.

Berger, J. (2000 [1972]). Modos de ver. Barcelona: Gustavo Gili.

Bonaudo, M. (Dir.) (1999). Nueva Historia argentina, Tomo IV: Liberalismo, Estado y orden burgués. Buenos Aires: Sudamericana.

Bonaudo, M. (2005). De la opinión publicada a la opinión pública. La prensa como lugar de representación y de conflicto. En M. Bonaudo (Dir.), Imaginarios y prácticas de un orden burgués, Rosario 1850-1930. Tomo I: Los actores entre las palabras y las cosas (pp. 71-95). Rosario: Prohistoria.

Bonelli Zapata, A. (2017). Imagen impresa y ciudad, Buenos Aires (1890-1910). InMediaciones de la Comunicación, 13(2), 99-127.

Bragoni, B. y Míguez, E. (Coord.) (2010). Un nuevo orden politico. Provincias y Estado Nacional, 1852-1880. Buenos Aires: Biblos.

Burucúa, J. E. (2006). Historia y ambivalencia. Ensayos sobre Arte. Buenos Aires: Biblos.

Caimari, L. (2015). El mundo al instante. Noticias y temporalidades en la era del cable submarino (1860-1900). Redes, $21(40), 125-146$.

Caimari, L. (2016). New from around the world. The newspapers of Buenos Aires in the Age of the Submarine Cable, 1866-1900. Hispanic American Historical Review, 96(4), 607-640.

Caimari, L. (2018). En el mundo-barrio. Circulación de noticias y expansión informativa en los diarios porteños del siglo XIX. Boletin del Instituto de Historia Argentina y Americana "Dr. Emilio Ravignani", 49, 81-116. Recuperado de: http://revistascientificas.filo.uba.ar/index.php/boletin/article/view/6566

Cavalaro, D. (1996). Revistas argentinas del siglo XIX. Buenos Aires: Asociación Argentina de Editores de Revistas.

Cibotti, E. (1993). El Mosquito de Enrique Stein, un ejemplo del periodismo faccioso de la década del 80. IV Jornadas Interescuelas de Historia. Mar del Plata: Universidad Nacional de Mar del Plata.

Díaz-Duhalde, S. (2014). El globo aerostático y la máquina de mirar. Cultura visual y guerra en el siglo XIX paraguayo. Decimonónica, Journal of nineteenth Century Hispanic Cultural Production/Revista de producción cultural hispánica decimonónica. 11(2), 34-51. Recuperado de: https://www.decimononica.org/wp-content/up loads/2014/06/Diaz-Duhalde_11.2.pdf

Fritzsche, P. (2008). Berlín, 1900. Prensa, lectores y vida moderna. Buenos Aires: Siglo XXI.

Freud, S. (2000 [1914]). El moisés de Miguel Ángel. En S. Freud, Obras completas, Tomo XIII: Tótem y tabú y otras obras (pp. 215-242). Buenos Aires: Amorrortu.

Galassi, G. (2012). Ciudad y modernidad: Rosario bajo la lente. Rosario: El ombú.

Garabedian, M., Miranda, L. y Szir, S. (Coords.) (2009). Prensa Argentina siglo XIX: imágenes, textosy contextos. Buenos Aires: Teseo.

Garavaglia, J. C. (2001). De Caseros a la Guerra del Paraguay el disciplinamiento de la población campesina en el Buenos Aires postrosista (1852-1865). Illes i Imperis, 5, 53-80. Recuperado de: https://www.raco.cat/index.ph $\mathrm{p} /$ IllesImperis/article/view/69411 
Garavaglia, J. C. (2007). Construir el Estado, inventar la nación: el Río de la Plata, siglos XVIII-XIX. Buenos Aires: Prometeo.

Garavaglia, J. C. y Gautreau, P. (2011). Mensurar la tierra, controlar el territorio. América Latina, siglos XVIII- XIX. Rosario: Prohistoria.

Gay, P. (1992). La experiencia burguesa. De Victoria a Freud. Tomo I: La educación de los sentidos. México: Fondo de Cultura Económica.

Gay, P. (2007). Modernidad. La atracción de la herejia, de Baudelaire a Beckett. Barcelona: Paidós.

Gayol, S. (2000). Sociabilidad en Buenos Aires. Hombres, honor y cafés 1862-1910. Buenos Aires: del signo.

Gionco, P. (2016). De arenas, escenas y otras cuestiones públicas. Espectáculos y convergencia cultural en las páginas de El Mosquito. En S. Szir (Coord.), Ilustrar e imprimir. Una historia de la cultura gráfica en Buenos Aires, 1830-1930. Buenos Aires: Ampersand.

Ginzburg, C. (1994) Microhistoria: dos o tres cosas que se de ella. Manuscrits. Revista d'história moderna, 12, 13-42.

Ginzburg, C. (2013). Mitos, emblemas e indicios. Buenos Aires: Prometeo.

Giunta, R. (1994). Buenos Aires en el Correo del Domingo. Anuario del Instituto de Arte Americano e Investigaciones Estéticas, 54(2). Buenos Aires, Facultad de Arquitectura, Urbanismo y Diseño, Universidad de Buenos Aires.

Giunta, R. (2002). Imaginando una modernidad. Anuario del Instituto de Arte Americano e Investigaciones Estéticas, 38, 137-166. Buenos Aires, Facultad de Arquitectura, Urbanismo y Diseño, Universidad de Buenos Aires.

Giunta, R. (2006). La gran aldea y la revolución industrial: Buenos Aires 1860-1870. Buenos Aires: El autor. Recuperado de: http://rodolfogiunta.com.ar/publicaciones/libros/Gran\%20Aldea\%20revolucion\%20industri al.pdf.

González Bernaldo De Quirós, P. (2008 [1999]). Civilidad y política en los orígenes de la nación argentina. Las sociabilidades de buenos Aires, 1829-1862. Buenos Aires: Fondo de Cultura Económica.

González Bollo, H. (2014). La fábrica de cifras oficiales del Estado argentino (1869-1947). Bernal: Universidad Nacional de Quilmes.

González Bonorino, J. (2005). La ciudad de Buenos Aires y sus habitantes 1860-1870 a través del catastro de Beare y el censo poblacional. Buenos Aires: Instituto Histórico de la Ciudad de Buenos Aires.

Gorelik, A. (2003). Lo moderno en debate: ciudad, modernidad, modernización. Universitas Humanísticas, 56, 10-27. Pontificia Universidad Javeriana.

Halperín Donghi, T. (1982). Proyecto y construcción de una nación. Caracas: Biblioteca Ayacucho.

Hobsbawm, E. (2006 [1975]). La era del capital: 1848-1875. Barcelona: Crítica.

Jay, M. (2003). Campos de fuerza: entre la Historia intelectual y la crítica cultural. Buenos Aires: Paidós.

Jiménez J. (1994). Una genealogía del espíritu moderno. En J. Glusberg, Orígenes de la modernidad. ModernoPremoderno: de Perreault a Rimbaud (pp. 1-8). Buenos Aires: Emecé.

Liernur, F. (1992). Una ciudad efímera. Consideraciones sobre las características materiales del Buenos Aires en la segunda mitad del siglo XIX. Estudios Sociales, 2, 103-121.

Mainardi, P. (2017). Another World: nineteenth-centruy Illustrated print culture. New Haven and London: Yale University Press.

Malosetti Costa, L. (1995). Los desnudos de Prilidiano Pueyrredón como punto de tensión entre lo público y lo privado. En VI Jornadas de Teoría e Historia de las Artes (pp. 136-139). Buenos Aires: CAIA.

Masán, L. A. (2017). El recuerdo como experiencia vital moderna. Las fotografías de Esteban Gonnet en el Buenos Aires de 1860. Estudios del ISHiR, 7(19), 65-81.

Matallana, A. (1999). Humor y politica: un estudio comparativo de tres publicaciones de humor político. Buenos Aires: Eudeba.

Mitchell, W. (2003). Mostrando el ver: una crítica de la cultura visual. Estudios visuales, $N^{o} 1$ : Los estudios visuales en el siglo XXI, 17-40. 
Ogando, M. (2000). El mosquito. En Ogando, M. (et. al.), Historia de revistas argentinas. Buenos Aires: Asociación Argentina de Editores de Revistas.

Osterhammel, J. (2015). La trasformación del mundo. Una historia global del siglo XIX. Barcelona: Crítica.

Oszlak, O. (1982). La formación del Estado argentino. Buenos Aires: Editorial de Belgrano.

Pastormerlo, S. (2016). Sobre la primera modernización de los diarios en Buenos Aires. Avisos, noticias y literatura durante la Guerra Franco-Prusiana (1870). En V. Delgado, y G. Rogers (Eds.), Tiempos de papel: publicaciones periódicas argentinas (siglos XIX-XX) (pp. 13-36). La Plata: Universidad Nacional de La Plata/FaHCE. Recuperado de: http://www.memoria.fahce.unlp.edu.ar/libros/pm.488/pm.488.pdf

Roman, C. (1999). La modernización de la prensa periódica, entre la Patria Argentina (1879) y Caras y Caretas (1898). En N. Jitrik (Dir.), Historia critica de la literatura argentina, Vol. III: el brote de los géneros. Buenos Aires: Emecé.

Roman, C. (2010). La prensa satírica Argentina del Siglo XIX: palabras e imágenes (tesis doctoral, 2 vols.). Buenos Aires: Universidad de Buenos Aires. Recuperada de: http://repositorio.filo.uba.ar/handle/filodigital/1613.

Roman, C. (2017). Política, prensa y cultura visual: "El mosquito" (Buenos Aires, 1863-1893). Buenos Aires: Ampersand.

Sabato, H. (1998). La politica en las calles. Entre el voto y la movilización, Buenos Aires, 1862-1880. Buenos Aires: Sudamericana.

Sabato, H. (2012). Historia de la Argentina, 1852-1890. Buenos Aires: Siglo XXI.

Saítta, S. (1998). Regueros de tinta. El diario Crítica en la década de 1920. Buenos Aires: Sudamericana.

Sidicaro, R. (1993). La política mirada desde arriba. Las ideas del diario La Nación 1909-1989. Buenos Aires: Sudamericana.

Simmel, G. (2005). La metrópolis y la vida mental. Bifurcaciones. Revista de estudios culturales urbanos, 4. Talca, Universidad Católica del Maule.

Singer, B. (1996). Three. Modernity, Hiperstimulus, and the Rise of Popular Sensationalism. En L. Charney \& V. Schwartz (Ed.), Cinema and the invention of modern life (pp. 72-99). Berkeley: University of California Press.

Schama, S. (1996). Landscape and memory. New York: Vintage Books.

Szir, S. (2009). De la cultura impresa a la cultura de lo visible. Las publicaciones periódicas ilustradas en Buenos Aires en el siglo XIX. En Garabedian, M., Szir, S. y Miranda, L. Prensa argentina siglo XIX. Imágenes, textos y contextos (pp. 53-84). Buenos Aires: Ediciones Biblioteca Nacional/Teseo.

Szir, S. (2013). Reporte documental, régimen visual y fotoperiodismo. La ilustración de noticias en la prensa periódica en Buenos Aires (1850-1910). Caiana, 3. Recuperado de: http://www.ahira.com.ar/wp-content/uploads/2018/09/Szir-Reporte-documental-r\%C3\%A9gimen-visu al-y-fotoperiodismo.-La-ilustraci\%C3\%B3n-de-noticias-en-la-prensa-peri\%C3\%B3dica-en-Buenos-Aires-189 0-1910.pdf

Szir, S. (2016) (Coord.). Ilustrar e imprimir. Una historia de la cultura gráfica en Buenos Aires, 1830-1930. Buenos Aires: Ampersand.

Szir, S. (2017). Imágenes y tecnologías entre Europa y la Argentina. Migraciones y apropiaciones de la prensa en el siglo XIX. Nuevo Mundo. Mundos nuevos. Recuperado de: https://journals.openedition.org/nuevomundo/70851

Szir, S., Munilla Lacasa, L. y Gluzman, G. (2013). Multiplicación de imágenes y cultura visual. Bacle y el arribo de la litografía a Buenos Aires (1828-1838). Separata, imágenes impresas, 13(18):. Centro de investigaciones del Arte Argentino y Latinoamericano, Universidad Nacional de Rosario.

Telesca, A. y Amigo, R. (1997). La curiosidad de los porteños. El público y los temas de vistas ópticas en el Estado de Buenos Aires (1852-1862). En Historia de la fotografia. Memoria del V Congreso de Historia de la Fotografia (pp. 33-36). Buenos Aires. 


\section{Notas}

1 Este trabajo se inscribe como parte de una investigación más amplia de carácter doctoral en la cual examinamos la conformación de una cultura visual de naturaleza moderna en el Buenos Aires de 1860 a partir de las pinturas rurales de Prilidiano Pueyrredón.

2 Salones como el del Recreo, las Delicias o Poliorama ofrecían diferentes vistas de ciudades y objetos visuales variados, desde máquinas electromagnéticas y juguetes, hasta piezas de Ópera y gabinetes de lectura con diarios de la capital y las provincias (El Nacional, año V, n. ${ }^{\circ} 1445$ y n. ${ }^{\circ}$ 1452, Buenos Aires, 12/3/1857 y 20/3/1857). Además de estos escenarios, existía una cantidad creciente de proyectos empresariales vinculados a las imágenes tales como los establecimientos de Alexander, Gonnet, Etchepareborda, Lahore o Mecks \& Kelsey, por citar sólo algunos de los más destacados (La Tribuna, año IX, 2260 y 2268, 28/6/1861 y 12/7/1861).

3 Llamada en sus orígenes "Poliautografía", la litografía creada por el bávaro Alöys Senelfelder (1771-1834) a finales del siglo XVIII significó un avance sustancial en materia de reproductibilidad tecnológica de las imágenes, tanto por su rapidez como por su fidelidad, posibilitando una nueva gama de aplicaciones que dinamizaron la cultura visual del siglo XIX, llegando incluso a transformar la práctica del dibujo de una actividad privada en una pública (Mainardi, 2017, p. 13).

4 Roman apela a este caso de "ausencia iconográfica" en El Mosquito para "graficar" el carácter de simbiosis visual entre palabra e imagen de la publicación. La jerarquización de la imagen que evidentemente promueve la publicación refuerza precisamente nuestro postulado en tanto, como afirma la autora, El Mosquito "avanzó con decisión hacia la autonomización de su plano visual y fue presentando a los lectores modos cada vez más complejos de vinculación entre palabra e imagen" (Roman, 2017, pp. 95 y 71).

5 El catastro del ingeniero británico Peter Beare fue realizado entre 1860 y 1870 y consta de 14 tomos, los cuales contienen más de 700 planos y de 5000 imágenes detalladas de cada manzana y propiedad de la ciudad (González Bonorino, 2005).

6 Para un análisis del desarrollo de esta institución estatal, la normativización de la mensura, las herramientas empleadas para la estandarización del trabajo en el Departamento Topográfico y el procedimiento por medio del cual se definieron las relaciones de la administración con sus empleados públicos y agentes, véase especialmente: Pierre Gautreau y Juan Carlos Garavaglia, "Inventando un nuevo saber estatal sobre el territorio: la definición de prácticas, comportamientos y agentes en las instituciones topográficas de Buenos Aires, 1824-1864" (Garavaglia y Gautreau, 2011, pp. 63-96). 